\title{
The Stylistic Potential of the Contextual Usage of Phraseological Units as Hybrid Formations
}

\author{
Rimma Abelhaerovna Safina ${ }^{1}$, Elena Valerjevna Varlamova ${ }^{1} \&$ Elena Antonovna Tulusina $^{1}$ \\ ${ }^{1}$ Kazan (Volga region) Federal University, Russian Federation \\ Correspondence: Rimma Abelhaerovna Safina, Kremlevskaya str., 18, Kazan, 420008, Russian Federation. \\ E-mail: rsafina@mail.ru
}

Received: March 29, 2015 Accepted: May 3, 2015 Online Published: July 30, 2015

doi:10.5539/ass.v11n19p64 URL: http://dx.doi.org/10.5539/ass.v11n19p64

\begin{abstract}
This article is devoted to the analysis of the certain contextual transformations of phraseological units. On the example of German journalistic texts the most popular types of modifications are described and analyzed. In the center of our attention is the semantic component and the processes which make this or that transformation possible. Also we consider stylistic functions of the usage of a certain transformation. The other important stage of our analysis is the attempt to explain the frequent usage of transformed phraseological units in journalistic texts. It is found out that such transformations have a leading role in the formation of the structure of the text, serve to produce certain stylistic effects and influence the reader on the emotional level.
\end{abstract}

Keywords: phraseological unit, contextual usage, stylistic functions, journalistic texts

\section{Introduction}

In the scientific works on phraseology it is almost customary to emphasize that phraseological units should be treated as linguistic signs of a special intermediate level. A dual nature of phraseological units is reflected in the majority of their definitions. Let us give some examples of such definitions.

Phraseological units are the set word-complexes of different structural types, the meaning of which emerges as a result of a complete or partial semantic transformation of the composition (Chernisheva, 1970). According to A. V. Kunin, a phraseological unit is a set combination of words with a complete or partial change of meaning (Kunin, 1972). V. P. Jukov characterizes phraseological units as synthetic, hybrid units which are situated in the focus of correlation of various layers, but do not create some distinct layer themselves (Jukov, 1996). The specific character of phraseological units is supported by the fact that on the one hand they have a form of word combinations, and on the other hand they acquire cohesive meaning and like lexical units have a nominal function. Due to this, the set expressions combine such unique features as separability of their structure and idiomatic character of meaning, which testifies to interrelation within the idioms of lexical and syntactical semantics.

Another important aspect connected with the hybrid character of phraseological units reveals itself in the content of the units. In the semantics of phraseological units the actual meaning comes into contrast with the etimological meaning. In the process of communication it is the actual meaning that goes into the foreground. Along with it, the phraseological units have their inner form which determines the understanding of the meaning of a phraseological unit (Jukov, 1978).

The dual nature of phraseological units reveals itself in the correlation between the semantics of distinctive components of phraseological units and the cohesive phraseological meaning. It is known that the structure and semantics of phraseological units is rather varied, the latter can be characterized by complete and partial idiomaticity, i.e. complete or partial nonderivability of the meaning of the unit from the values of its components. From the point of view of realization of the stylistic functions of phraseological units the most interesting is the group the components of which have partially preserved the structural and semantic independence. Due to this the stable structure of a phraseological unit loses its stability.

Considering the problem of semantic separability of phraseological units, D. Dobrovolskij and E. Piirainen point to the fact that different contextual modifications of a certain phraseological unit can be regarded as the major testimony of the semantic independence of the components of such set expression. The scholars prove this thesis 
on the examples of structural and semantic transformation of the phraseological unit "make a slip":

- The boss will not forgive him the slip he has made.

- He has made a slip several times already.

- What slip has he made?

- Not once he has made a slip in his life.

- He has made "a slip of the day" (Dobrovolskji \& Piirainen, 2008).

These modifications of the given phraseological unit proved possible due to the fact that the unit itself has a separable inner form and can be divided semantically into the components according to the structure of the unit. The strong lexeme "slip" (in the meaning "mistake") acquires an attributive extension, which leads to a complex imaginative ground, appearance of the additional some of irony and heightening of the expressive potential of the unit. Thus, it can be said that it is the cooperation of three factors-the separable structure, the separable inner form, the structural and semantic independence of the components of a phraseological unit-that is in the basis of the transformation of a phraseological unit in the text.

\section{Methodological Part}

The aim of the study is to reveal the stylistic potential of the contextual usage of phraseological units as hybrid formations. In the focus of our attention are certain transformations of phraseological units which take place in various journalistic texts by German writers. It should be pointed out that transformed phraseological units thanks to their unusual, renewed form, heightening of expressive and emotional connotation and the power of the impact on the recipient are a favorite expressive means in the journalistic sphere and represent today a big layer in modern German journalism.

The abundance of transformed phraseological units in genres relating to news and analytical genres is connected, on the one hand, with the fact that these genres take the biggest part in the modern publicistic writing, and, on the other hand, with the stylistic peculiarities if these genres. Among the analytical genres the biggest part of transformed phraseological units can be found in commentaries, reviews and analytical correspondence. All these genres are characterized by understanding of the information, analysis and the authorial interpretation of the situation, w high leads to the usage of phraseological units with a certain aim: to put emphasis on the expressive and evaluative components. In spite of the fact that news oriented genres are aimed primarily at the fact, they employ transformed phraseological units to make the vivid and laconic style of their works more expressive. It refers, first of all, to personals and reports. Less frequent the number of transformed phraseological units in annals. The frequent usage of the given units in interviews, dialogues and talks is predestined by the fact that all these genres belong to varied speech which adores the filling of the text with such like components. Along with it, such texts should be precise in giving information and revealing the attitude of the interlocutor. It is not typical for the epistolary to use the transformed phraseological units, which can be connected with the individual manner of the authors.

Within other genres the biggest part of transformed phraseological units is typical for feuilleton, which is well understood, as it is the satirical genre. Less remarkable is the number of transformed phraseological units on reports, which are becoming rarer in newspapers.

Besides, modified phraseological units can be found in journalistic investigations, jokes, ratings, travel essays, catchwords, sociological researches, obituaries. Newspaper publications are characterized by the mixture of genres.

A considerable frequency of transformed phraseological units in the newspapers is connected both with the popularity of journalistic genres in modern press and with the functions of this or that genre, as well as with peculiarities of the stylistics. Penetration of analytism, personal evaluation, devices of artistic portrayal, irony into a lot of genres of newspaper journalism is well observed nowadays, which leads to a wider use of transformed phraseological units. To produce the expressiveness of their texts, the authors apply to the certain types of transformations, based on the emergence of authorial, contextual units. Transformed phraseological units used in certain context are typical for all genres, including the news oriented genres, which perform increasingly great democratization of the language. As a rule transformed phraseological units have several stylistic functions in the text.

The results of the text studies of the magazines Spiegel, Focus, and the newspaper Berliner Zeitung (online-record 2002-2012) have shown that the most productive transformations of the lexical layer are extension of the composition, ellipsis, and substitution of one or several components. Let us study each of the 
types of the transformations named and decide what the aim of the exact transformation is and what its stylistic potential is.

\section{Results}

\subsection{Results}

The first type of modification is the extension of the composition of a phraseological unit. It means that in the structure of the unit one or several additional components are included. I. N. Kuklina explains the phenomenon of this device as the expression of a formal excessiveness, typical due to the structural separability and flexibility of the borders of the units (Kuklina, 2006). As a rule the extension serves as a means of particularization and is employed to connect the meaning of a phraseological unit with a certain context as in the example:

So, she is trying to make the poverty virtue, and unavoidably uses the emerged new player space in her favor (Neukirch \& Schult, 2004).

In this example the author extends a very customary in the modern journalism set expression "to use a player space", expanding it with a number of attributes ("unavoidably", "new", "in her favor"). The introduction of additional components lets the journalist to give a more precise and detailed characteristics of the strategy of the political activities of the team of Anhela Merkel.

In some examples the introduced components do not even particularize the semantic structure of a phraseological unit, but serve to intensify the semantics, heightening the expressive potential of the unit.

Such phenomena can be observed in the following example:

In politics it's important not to rest just on the first layrels (Tietz \& Tuma, 2004).

In this sentence the phraseological unit "to rest on laurels" is expanded by the ordinal numeral "first" and the modifier of time "just". As a result, the expressiveness of the unit is increased, the author appeals to the politicians not to stop after the first results have been achieved, but to continue their work.

Very often the extension is employed by the journalist to emphasize their personal perception of the topic, in such cases the tone of the expression can become ironical, or even satirical:

This appealed to them and became a very loud music to the ears for social democrats (Kurbjuweit, 2005).

The phraseological unit "music to the ears" is extended here ("a very loud music to the ears"), which makes the imaginative picture more vivid and bright. The Chancellor's approval is compared with an anaplerotic ointment from a big tube. The additional components add a humorous effect and make the speech of the author more expressive.

In a number of cases transformed phraseological units accomplish a text-building function. A transformed phraseological unit can go through the whole text as a keynote, which helps to make the test a unity. Thus, a modified phraseological unit "With milk foam at the mouth" is the headline of one of the feuilletons which says about the social importance of one of the online media outlets. In the middle of the text this phraseological unit is presented again in the form of the modified expression "with a big amount of foam at the mouth" and further in the metaphor "production of milk foam". In the final part of the feuilleton the phraseological unit appears again in the modified form "But again with a milk foam at the mouth", creating the frame-composition of the text and creating the emotional tension of argumentation and evaluation (Wahl, 2015).

\subsection{Results}

In the News Media texts which have been under the analysis another device is also very frequent along with the extension of the composition-ellipsis, the syncopation of the part of a phraseological unit. The functional distinctiveness of the composition of phraseological units in the texts of News Media can be easily explained: one of the main principles of journalistic genre is brevity, laconism, and informational capacity.

In the majority of cases ellipsis can be found in the headlines. The headline in the newspaper is always accentuated; it's the first thing a reader pays attention to. A bright headline with a phraseological unit in its composition is the basis of the public's interest; it's a kind of some warm-up which invites a reader to experience something new and absorbing. For example, "Fast grip", "Bitter tears". In the examples given, the syncopation of the verbal components do not destroy the vividness of the expressions, the loss of the latter do not produce any semantic shifts. It's important to note, though, that the absent component has a considerable semantic filling. In this case the author expects that the reader knows the original phraseological unit that he can reconstruct it in his mind, and the usage of the ellipsis in this case is aimed at the attention drawing.

In our opinion, the functional distinctiveness of ellipsis is not only in shortening of information, it also implies 
something unspoken, something that can arouse interest, and leave the space for self-understanding of a phraseological unit. For example, in the "Cold in hand, heavy expenses" (The Contents, 2005) we come across two ellipticated set phrases at once, these units have mutually exclusive semantics. The logical question here that comes into the mind is whether it's possible or not to spend a lot not having money. Based on the contrast, the headline draws the universal attention.

In the majority of headlines the elliptical construction of set phrases leads to the literalization of their meaning, which is supported by the meaning of the whole text of the article. For example in the article under the "Body and soul" is said about a healthy life-style, about a close relation between psychological processes and the physiology of a person.

Taking into account the given facts and examples, we can come to the conclusion that ellipsis encourages not only the informational richness, but in some cases leads to more complex semantic transformations of phraseological units.

\subsection{Results}

Next, as well very important for the journalistic genre, transformation is substitution, which can be revealed in the replacement of one or several components of a phraseological unit by one, or also several lexemes. Under substitution are not only the main parts of speech, but also conjunctions, prepositions, etc, which unavoidably leads to changes in the semantic meaning. For example, in some phraseological units the substitution of a mere conjunction leads to the literalization of a set phrase. In the transformed unit each component begins to acquire its own lexical meaning.

In the studies of constitution the major attention of the linguists is drawn to the interrelation of correlates, i.e. substitutes and substituted components. In this relation the German scientists distinguish two major types of substitution: paradigmatically based substitution and contextually based substitution (Barz, 1986, pp. 321-336), (Ptaschnyk, 2001, pp. 235-254).

In the first case we speak about the units in which the lexeme-substitute is in certain paradigmatic relations with the substituted lexeme. Very often the correlates are stylistic synonyms, or refer to one and the same lexical field, which can be distinctly seen in the following phraseological unit:

"How to spend our money? That is the problem. But not for the German top enterprises which live their Golden Autumn now" (Deckstein et al., 2004). In this case, in the phraseological unit "the Golden Age" instead of the component "Age" the lexeme "Autumn" is used, which leads to the narrowing of the meaning of the set phrase. Thanks to the substitution of the components the meaning of the phraseological units correlates with the season of the year: "it's the Golden Age for the enterprise now", or "the Golden Autumn".

In the transformations of the second type the lexeme-substitute is not connected with the initial phraseological unit, and acquires a new meaning only in the new context. This type of modification is represented in the headline "A domineer can go a long way" (Opitz, 2002). The article under the headline is about the election win of one very famous in Germany politician. The initial phraseological unit "A little can go a long way" preserves its semantic meaning, but due to the transformation it acquires some new, additional understanding: the substitute "domineer" points to the culpability of the candidate to the ruling forces of great power.

\section{Discussion}

Vakurov V. N. admits that the usage of substitution has several linguistic aims: to accustom a phraseological unit to a certain linguistic situation, to transform a phraseological unit, to make the latter alive and vivid, to produce a humorous effect, to show the attitude to the situation (Vakurov, 1980). Let us consider the realization of the functions listed in the concrete examples.

Some especially popular quotations have become a kind of models, forms in which one of the components is substituted according to the context. One of the favorite examples for transformations is the phraseological unit of the bible origin "In the beginning was the Word". As a component for substitution the part "Word" is especially frequent here. For example, "In the beginning was the Picture". In the headline to one of the favorite feuilletons it is the first component of the set phrase that is substituted: "At the beginning was the word". Thus, the semantic accent is shifted from the object to the time span described in the article.

Very often the meaning of the substituted component contrasts with the meaning of the initial component, which claims the attention of the reader, creates the effect of unexpectedness, and, as the result, influences the emotions of the recipient. The transformed phraseological unit "Steal but verify" (Augstein, 2010) can serve here as an example. The reader knows the transformed phraseological unit "Trust but verify" and its meaning perfectly well, 
but the unusual composition, the change of evaluative connotation takes one aback and asks to search for the new meaning for the transformed phraseological unit, it definitely disappoints the expectations.

In a number of cases the interrelation of the correlates within the transformed unit has an even more complex character, as the substitution is made on the basis of the associative and imaginative coupling of the components (Ptaschnyk, 2001, pp. 235-254). In such cases it's rather difficult for the recipient to identify in the modified unit the initial one. But, as a rule, exactly such transformed units are more vivid and expressive, and apply to the reader more. For example, "Adenauer und Kohl are two names on hearing which even the most politically ignorant people have shivers storming feverishly up and down their skin" (Augstein, 2010). In the basis of the modified expression there's the phraseological unit "to have shivers running up and down one's spine". The verb "to run" that has a neutral connotation is substituted by the verb "to storm". Also, the new component "feverishly" is added the composition of the unit. As a result, the meaning of the initial phraseological unit is enriched by the seme of expressiveness and irony. The aim of the author is quite obvious: to make fun of the respect and horror which the people have when they hear the names of the famous politicians such as Adenauer und Kohl.

\section{Conclusion}

In the end, we would like to point out that it is the hybrid origin of the phraseological units that has in its essence the interrelation of lexical and syntactic semantics which overlooks the great possibilities for the realization of set expressions in the text. Such characteristics of a particular group of idioms as semantic dividedness and clarity of the inner form make it possible to change the meaning of a customary set phrase. Any changes in the composition of a figure of speech cause certain semantic changes, and the broadening of the connotative potential of a unit. As a rule, such transformations as extension of the composition or substitution of one of the components add some additional meaning to a phraseological unit, some new information which then, explicitly or implicitly, reveals itself in the text. A new, more complex image contributes to the appearance of a wide range of associations and additional connotations. Ellipsis, on the contrary, serves as means of shortening, releasing the phraseological unit from semantically excessive components. What is more, phraseological units acquire the text-building function. Modified phraseological units serve not only to draw the attention or some emotional evaluation, but also determine the composition and the system of images of the text. They are codified experience of all native speakers. This experience is very important and up to date for each language community (Ayupova et al., 2014, pp. 290-293). Most phraseological units have become international, and can be perceived by the bearers of different languages. "It is doubtless that the translation of the extracts containing such a device is a challenge to a translator's skills" (Arsenteva \& Kauymova, 2014, pp. 502-506).

\section{References}

Arsenteva, E. F., \& Kayumova, A. R. (2014). Complex modifications of phraseological units and the ways of their translation. Life Science Journal, 11, 502-506.

Augstein, R. (2010). Steal but verify. Der Spiegel, 52. Retrieved from http://www.spiegel.de/spiegel/print/d75936292.html

Ayupova, R. A, Bashirova, M. A., Bezuglova, O. A., Kuznetsova, A. A., \& Sakhibullina, K. A. (2014). Ornythonym component and phraseological meaning. Life Science Journal, 11, 290-293.

Barz, I. (1986). The problem of phraseological modifications. German as a foreign language, 23(6), 321-336.

Chernisheva, I. I. (1970). Phraseology of the Modern German Language. Moscow: The Higher School.

Deckstein, D., Dohmen, F., Jung, A., Martens, H., \& Pauly, C. (2004). Where to go with so much money? Der Spiegel, 48. Retrieved from http://www.spiegel.de/spiegel/print/d-37494676.html

Dobrovolskij, D., \& Piirainen, E. (2008). The Theory of phraseology. The cognitive and cultural aspects.

Jukov, A. V. (1996). Transitional phraseological phenomena in the Russian Language. Novgorod: The Novgorod State University.

Jukov, V. P. (1978). The Russian Phraseology. Moscow: The Higher School.

Kuklina, I. N. (2006). The phenomenon of phraseologisation and dephraseologisation in the language of modern.

Kunin, A. V. (1972). Phraseology of the modern Russian Language. Moscow: Foreign Relations press (Doctoral dissertation).

Kurbjuweit, D. (2005). Red-green mist. Der Spiegel, 12. Retrieved from http://www.spiegel.de/spiegel/print/d- 
39774186.html

Neukirch, R., \& Schult, C. (2004). Merkel's order. Der Spiegel, 49. Retrieved from http://www.spiegel.de/ spiegel/print/d- 38016888.html

Opitz, O. (2002). A domineer can go a long way. FOCUS Magazin, 28. Retrieved from http://www.focus.de/ politik/deutschland/ berlin-klein-aber-maechtig_aid_208354.html

Ptaschnyk, S. (2001). Phraseological Substitution and its functioning in the text. Wirkendes Wort, 11, 235-254.

Schmidt, H. (2002). Harold Schmidt is writing. FOCUS Magazin, 38. Retrieved from http://www.focus.de/ magazin/harald_schmidt/hier-schreibt-harald-schmidt-22 september_aid_208390.html

The Contents. (2005). Der Spiegel, 28. Retrieved from http://www.spiegel.de/spiegel/print/index-2005-28.html

Tietz, J., \& Tuma T. (2004). I hate the drawers. Der Spiegel, 48. Retrieved from http://www.spiegel.de/spiegel/ print/d -37494678.html

Vakurov, V. N. (1980). The basic concepts of the stylistic of the phraseological units. Moscow: The Russian Language.

Wahl, T. (2015). With a milk foam at the mouth. Berliner Zeitung. Retrieved from http://www.berliner-zeitung. de/archiv/oder-das-blatt-zur-bionade--die-neue-internetzeitung--prenzlauer-berg-nachrichten--klebt-fest-imeigenen-milieu-mit-milchschaum-vorm-mund,10810590,10762186.html

\section{Copyrights}

Copyright for this article is retained by the author(s), with first publication rights granted to the journal.

This is an open-access article distributed under the terms and conditions of the Creative Commons Attribution license (http://creativecommons.org/licenses/by/3.0/). 